\title{
shallow breath
}

\author{
Sandra Semchuk \\ in collaboration with James Nicholas
}

Let me tell a little about the territory that shallow breath came about in. I cannot begin at the beginning because you don't need to know the whole truth, a half is enough, I think.

It is a sunny hot day living on the transcanada highway, on a reserve west of Lytton, B.C. This is semi-arid. When I say hot I mean hot. In front of our apartment is an ancient graveyard. I don't know whose. There is some difference of opinion here. In front of that is the highway, in front of that is the Fraser Canyon with the River flowing through, in front of that is a railway line with a tunnel going through, in front of that is the mountain. What's in front of the mountain I don't know.

James and I have just returned from a healing conference for residential schools. I am heartbroken, devastated by the succession of stories told by men and women who endured residential school. The pain and rage in their voices, the courage it took for those who are still alive to stand before a hundred people, including medicine people and counsellors, and speak,

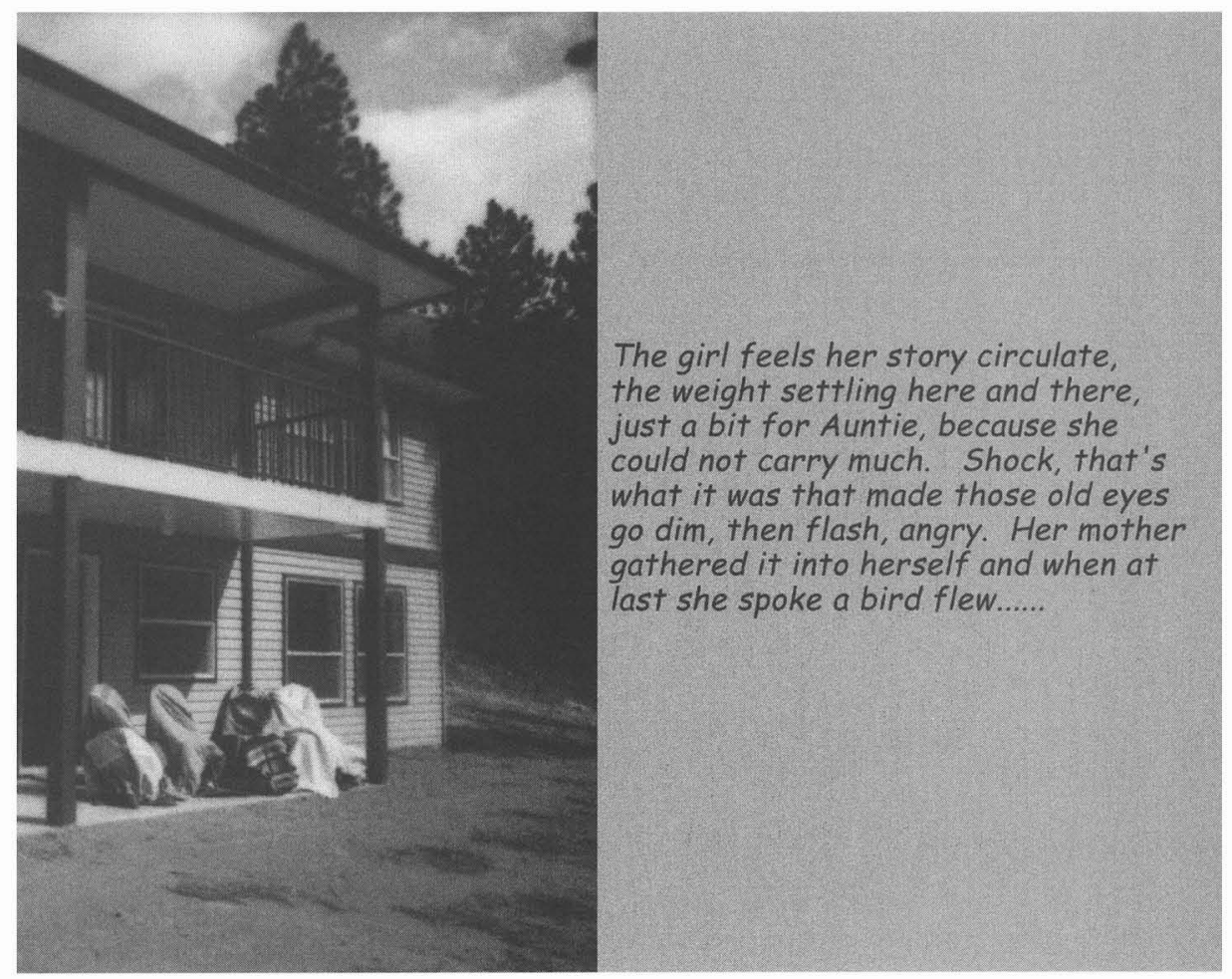


continues to resonate in my body. Nellie, James' sister, a medicine woman, and another elder sit on either side of me. I know that they are trying to give me the courage to speak, but I cannot. I cannot apologize like the Anglican minister or the bishop can. I represent only myself. And I am devastated. No single story could have this kind of impact, story after story after story. What could I say? What is the effect on James who went to residential school?

I am cleaning the apartment from top to bottom. Washing, washing everything. I take the chairs outside and over them I lay the blankets to air. Seeing the figures emerge, I am quiet. Last week James and I were invited to a memorial here. At one point the speaker came out and using hand gestures and speaking indicated that all cameras were to be put away. Chairs were brought out and the ritual evolved to where blankets were carefully placed over the chairs to honour the dead.

Last night James watched a newborn baby take its last two breaths. The child's mom was a crack addict. A survivor.

\section{he weight of shallow breathing} (weight restore shallow justice breath) 